\title{
The transition of Wytham Woods from a working estate to unique research site (1943-1965)
}

\author{
K. J. Kirby
}

Department of Plant Sciences, South Parks Road, Oxford, OX1 3RB, UK; tel (44) 755728

2711; email keith.kirby@bnc.oxon.org

\section{ACKNOWLEDGEMENTS}

The Elton Archive material was made available by permission of his family and the Department of Zoology (successors to the Bureau of Animal Population) and Oxford Museum of Natural History via the Oxford Research Archive, through the work of Professor Caroline Pond who 'read-in' the entire oeuvre. Peter Savill and Arnold Grayson provided useful comments on a draft of this paper. Funding for the digitisation of the Elton Archive was organised by Nigel Fisher, Conservator of Wytham Woods, from the University of Oxford.

\begin{abstract}
Diaries written by Charles Elton and other unpublished material from 1942-1965 illustrate the state of Wytham Woods and debates about its management in the first two decades after the estate came into the ownership of Oxford University. They reveal a legacy of war-time activity, the problems of rabbit control and the tensions between the different departments in the University. The Forestry Department sought to manage most of the Woods as a resource for teaching the then prevailing ideas of modern productive forestry: most of the Woods should therefore be converted to plantation. Elton and others regarded the rates of felling and replanting, the loss of old trees, as a serious threat to the value of the Woods from an ecological research perspective. In 1961, the University sided with the ecologists and active forestry management largely ceased. The legacy of this period survives though in the composition and structure of the Woods today. The issues and debates at Wytham foreshadow many of those that took place in the 1970s and 1980s between foresters and conservationists more generally across Britain.
\end{abstract}

\section{KEYWORDS}

Wytham Woods, Elton, rabbits, forest management, woodland conservation

\section{INTRODUCTION}

Wytham Woods, near Oxford, were acquired by the University in 1942 (Anon 1943) and are one of the most studied forests in the world. Yet, during preparations for a book about such research (Savill et al. 2010) it became evident that little had been published on the early decades of University ownership.

Diaries written by Charles Elton, then Director of the Bureau of Animal Population, Oxford (Crowcroft 1991 and Table 1) include notes of c.400 visits to the Woods between 1942 and 1965. These data together with other, largely unpublished, material illuminate the transition from a traditional woodland estate to the elite research site that it has become (Savill et al. 2010). The attitudes and actions revealed by this material help to explain the present day structure and composition of the Woods. 
Table 1. Key individuals referred to in the subsequent account.

\begin{tabular}{|l|l|}
\hline Col. Raymond ffennell & Owner of the Wytham Estate 1920-43 \\
\hline Mr Venables & Shooting tenant \\
\hline The Forestry Department & \\
\hline R.L.Troup & Professor, 1920-1939 \\
\hline H. Champion & Professor, 1939-1959 \\
\hline M.V. Laurie & Professor, 1959-1969 \\
\hline F.C. Osmaston & Lecturer, Silviculture \\
\hline E.W.Jones & Lecturer, Forest Ecology \\
\hline & \\
\hline The ecologists & \\
\hline C.S.Elton & Director, Bureau of Animal Population \\
\hline H.N.Southern & Senior Researcher at the Bureau \\
\hline D. Lack & Director, Edward Grey Institute \\
\hline & \\
\hline Other University officials & \\
\hline Mr Bredin & $\begin{array}{l}\text { Representative of the Curators of the University } \\
\text { Chest (the University's Finance Office) }\end{array}$ \\
\hline & \\
\hline Wytham Woods staff & \\
\hline H. Probitts & Forester, \\
\hline D. Meads & Gamekeeper \\
\hline & \\
\hline
\end{tabular}

SITE

Wytham Woods cover about 400 ha, located just north-west of Oxford in southern England (Savill et al., 2010, Elton, 1966, Grayson \& Jones, 1955) (Figure 1).

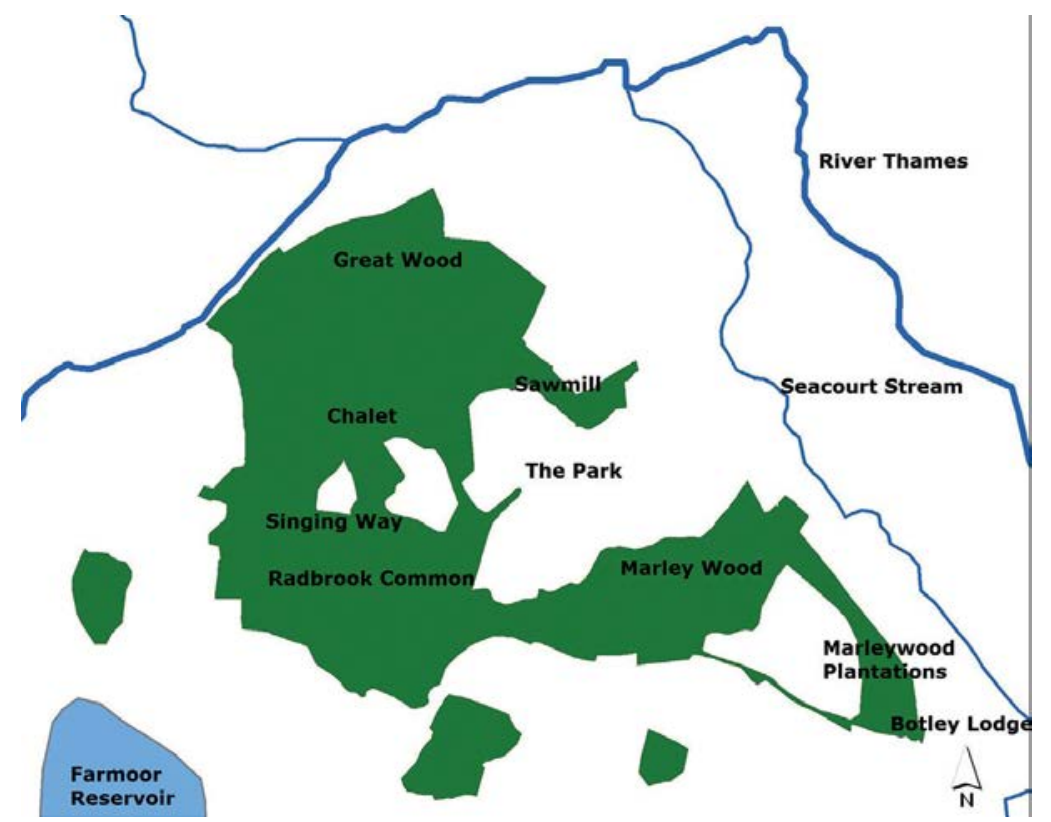

Fig. 1. Outline of Wytham Woods indicating places referred to in the text, modified from original by Michele Taylor in Taylor et al. (2010). 


\section{SOURCES AND METHODS}

Charles Elton's notes of his visits to Wytham Woods and to other places between 1942 and 1965 were deposited in the Museum of Natural History in Oxford after his retirement from the Bureau of Animal Population, but their existence and significance were not widely appreciated. In 2013 a project was started to make them available in digital form. Professor Caroline Pond, read and edited the texts using voice-recognition software and they are now available as part of the Oxford Research Archive (Elton 1943-1965).

Most years in the period 1943-65 Elton recorded 10-15 visits to Wytham Woods, with a slight bias towards spring and autumn. Nowadays access to the Woods is generally from the Sawmill in the north-east (Figure 1), but then the Botley Lodge entrance in the south-east was easier to get to on bicycles (no hills are involved) or bus from the centre of Oxford. There is therefore something of a bias in his entries towards the east and south of the Woods.

The visits were not a systematic, planned survey: they were fitted in amongst other duties including visits to sites elsewhere in Britain (recorded in a separate series of notebooks) and, in the first few years, wartime activity. On any one visit what was recorded depended on the conditions, concerns and time available. Caution must therefore be applied, particularly with inferences based on what is not mentioned.

These insights into the state of the Woods and their management between the 1940s and 1970s have been supplemented by:

- aerial photographs from the 1940s held in the Wytham Woods office;

- unpublished management plans produced by the Oxford Forestry Department (Anon, 1950, Osmaston, 1959);

- unpublished notes and correspondence relating to the Biological Committee for Advice on University Estates (1943-46; 1961).

\section{RESULTS}

\section{THE WOODS PRIOR TO UNIVERSITY OWNERSHIP}

The Woods had been actively managed for timber and coppice products during the $19^{\text {th }}$ century when they were owned by the Earls of Abingdon, as evidenced by references to wood sales in Jackson's Oxford Journal (R.C.Thomas, quoted in Gibson and Kirby (2010, p.39). Extensive felling of timber is also reported to have occurred between 1900 and 1912 (Osmaston 1959), and perhaps during the first world war. Practice trenches were dug across parts of Radbrook Common. The Woods were also used for shooting with, for example ponds created or enlarged to improve the potential for duck.

In 1920 the Woods were bought by Raymond ffennell (born Schumacher) who had made money in the mining business in southern Africa. He had previously rented Wytham Abbey while on a visit to England in 1916 and seems to have fallen in love with the area then (Perrins 2010, pp9-13) . The Woods continued to be used for shooting parties and there was some forestry management. Small conifer plantations were created in the 1920s and 30s, but the bulk of the woodland remained broadleaved: the main species being oak (Quercus robur), beech (Fagus sylvatica), ash (Fraxinus excelsior) and sycamore (Acer pseudoplatanus), with hazel (Corylus avellana) as the main understorey species. There was still a limited market for 
coppice products to supply the local agricultural markets (pea sticks, bean rods, thatch rods, posts and stakes, and at least some of the timber was of good quality (Anon 1950; Osmaston 1959).

Raymond ffennell was also a philanthropist. In South Africa he had given his old home to house convalescent children; at Wytham he set up Hill End Camp (which still exists) as an outdoor education base; was involved in the foundation of the Oxford Preservation Trust; and made substantial gifts of land to the City of Oxford. His daughter Hazel seems to have enjoyed exploring the estate and had an affinity with animals amongst other talents. However, she died young (aged 35) in 1939. With no other immediate heir the ffennells decided to give the Woods to the University and this transfer happened in 1942 (Perrins 2010, pp9-13; Anon, 1943)

\section{WYTHAM DURING WORLD WAR II}

As elsewhere in the country felling took place in Wytham Woods between 1939 and 1945 as part of the war effort and organised by the Ministry of Supply (Table 2) (Foot 2010). Aerial photographs from the 1946 period show a relatively open canopy (Figure 2) although the cutover areas had started to regrow.

Another, but indirect, legacy of the war was on land-use policy and its effect on the attitudes of those involved in teaching agriculture, forestry and ecology: there was a pressure to increase home-grown food and timber, but also a growing recognition of the application of ecological science to land-use. These national trends were reflected in subsequent debates on the management of Wytham Woods.

Table 2. Wartime activity and subsequent regrowth (extracts from Elton (1942-65))

11 April 1944 On the hot grass-patched track up from Botley Lodge, which runs in its lower 2/3 between narrow strips of smashed copse - very open, or cut....

28 April 1945 Radbrook Common, formerly a sort of brackeny heath on regressive woodland, has mostly been ploughed for poor cereal crops.

24 August 1945 Went to the north end. Met Prof. H.G. Champion and his forester (Probitts), just appointed. Saw Ministry of Supply gang beginning to take out sycamore on the way from the village to the Chalet.

21 September 1945 There is much sycamore cutting by the Ministry of Supply men in the far part of Common Piece, leaving open wood cleared of all except selected trees, and with underbrush and toppings burned. Tracks rather badly cut up by lorries.

10 June 1947Areas thinned of sycamore a year or two ago by the Ministry of Supply are thickly growing up with coppice of sycamore and elder, and ground vegetation.

23 September 1947 Near Lord's Common a lot of sycamore coppice about $8 \mathrm{ft}$. high is coming up after the Ministry cuttings two years ago.

10 September 1948 The rides have quite recovered from the smashing they had with the Ministry of Supply tractors two or three years ago. 


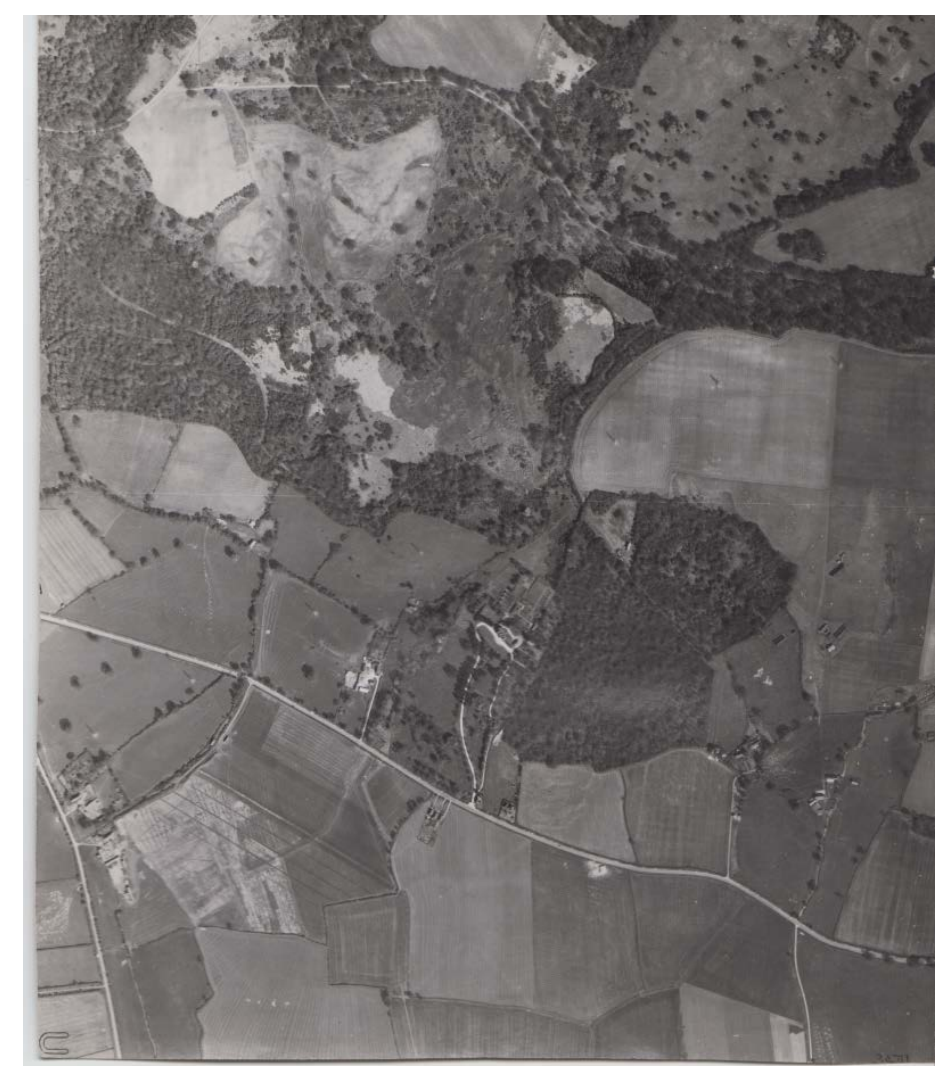

Figure 2. 1946 Aerial photograph showing south-west corner of the woods and the openness of the canopy; a largely treeless Radbrook Common (courtesy of Conservator of Wytham Woods).

\section{The legacy of a shooting estate}

When Colonel ffennell acquired the Estate in 1920 a major interest was its sporting use pheasants, rabbits and some duck shooting. When the Woods were transferred to the University they came with a shooting tenant (Mr Venables) who was also responsible for rabbit control. Early visits by Elton comment on the severity of the rabbit infestation (Table 3). During the War the Bureau of Animal Population had worked on the problems of pest control, so, not surprisingly, he was asked for his advice on how the rabbits might be better dealt with (Table 4). His suggestions were not taken up.

Table 3. The rabbit problem (Elton 1942-1965).

17 April 1943 The sycamores show traces of terrific rabbit ring-bark damage, which has either killed, or left great scars -- all old. Only one rabbit seen. The clearances of rabbits (whose former abundance may explain the frequency of elder in Wytham, and general poverty of interesting scrub) may allow spindle to multiply.

11 April 1944 These woods are in shocking decay, much of it through violent rabbit barking over recent years. Rabbit earths are numerous, some fresh. Several rabbits seen in 114 and the open park below it. Smell of fox at several points. I have never seen a woodland so smashed by the short-sighted policy of selling rabbiting rights (which mean rabbit perpetuation) in a country possessing insufficient pressure of natural rabbit control. 
28 April 1945 Walked round most of the outer fringe of the woods, from the Wytham side round to Radbrook Common, to see the extent of rabbit infestation. Apart from a general thin population of apparently surface living animals, of which traces were commonest at the wood margins, the only aggregations of buries [burrows] were in the sandy zone of the Calcareous Grit and Sands. Some of these had been gassed -- not very efficiently.

23 September 1947 Probitts said Venables' men only just check, do not exterminate the rabbits.

Table 4 Suggestion from Charles Elton to Professor Champion on how the rabbits might be dealt with (unpublished letters, March 1944)

1. Get two Land Girls to go round and cyanide gas the burrows (putting a spoon of Cymag in and blocking the hole). There are a good many buries about the wood, but I believe not many on the farm land. It would be vital to treat any warrens in the park. This must all be done before the vegetation gets up, i.e in April.

2. Trap and drive the rabbits from October onwards. The surface living population, being a large element in the woods would almost certainly have to be dealt with by open trapping, i.e. on the surface. This is against the law in peace time, but now legal under licence from the W.A.E.C. [War Agricultural Emergency Committees]. It undoubtedly involves the risk of killing various surface living predators such as foxes and there may be objections on this ground.

3. If the rabbits aren’t gassed now there will be heavy breeding before the autumn.

4. It is impossible to give a firm estimate beforehand but a couple of weeks work by two girls now would make a lot of difference. In the winter the sale of the rabbits would pay back a great deal of the costs. The whole net cost would therefore be less than $£ 50$, but one cannot be sure.'

In autumn 1946 the shooting tenant Venables reported that 1226 (including young) rabbits and 171 squirrels had been killed. Elton noted that this amounted to only about two per acre and H.N.Southern reported no real improvement in the situation. Elton concluded that Venables could not cover enough ground and did not use enough gas. Against Elton's advice rabbit control was left with the shooting tenant however. So on 30 November 1946 Elton wrote to Professor Champion that he would not offer any further comments on rabbit or squirrel control, though 'will give you personally all possible advice you may ask for unofficially'; 'the responsibility [for the rabbit control] is entirely out of our hands'.

In the event the arrival of myxomatosis in 1954 removed the problem (Sheail 1971) and later that winter Southern (1955) noted only one or two rabbit tracks in the snow. There has been some recovery in their populations but not to the levels where they are again a significant problem across the Woods. The remains of some of the pre-1950s warrens are however still detectable as areas of nettles and increasingly moribund elder bushes.

Pest control

Amongst the ecologists there was concern about the degree to which the sporting regime generally was compatible with their developing research programmes. In March 1945 the Biological Committee for Advice on University Estates (hereafter referred to simply as the 
Advisory Committee) recommended to the University Chest that the shooting lease should be terminated at the end of the 1946. H.N.Southern attended the discussions on behalf of the Bureau of Animal Population and at one point produced two dead tawny owls recently shot by sportsmen in Wytham, remarking 'here is 10\% of the population I am studying'. On 15 June 1946 Elton wrote to the University Chest that Venables's men had gassed and killed badgers on the slope below the Chalet, also a badger earth in Marley Wood which they promised to leave; and had been laying poisoned baits for foxes. The shooting tenancy was however renewed and continued until 1956.

The University had appointed a Warden/Gamekeeper in 1951 (Dane Meads) to control trespassers and to carry out some pest control (Osmaston 1959). This latter continued even after the game shooting stopped. A report to the Advisory Committee (9 March 1961) gives the following for the previous year:

- Grey squirrel control - 468 dreys destroyed, 490 squirrels shot;

- 211 rabbit holes gassed, 321 rabbits shot;

- 11 fox earths gassed; 13 killed plus 6 wounded, possible kills;

- Maize plots on Northfield Farm being damaged by badgers; sett just behind the Chalet 'treated' to stop this.

There continued to be a gamekeeper on the books until the 1990, but 'pest control' played less and less of a role.

\section{Forest management 1943-1960}

During the 1930s R.L.Troup (Professor of Forestry) had discussions with Colonel ffennell about taking over the management of Wytham Woods, but nothing came of this. When the Woods did come to the University, however, there was no land agent in the Estates Division, so the Forestry Department assumed responsibility for the future management of the Woods. Initial surveys of the Woods were carried out and a ten-year management plan produced (Anon 1950) (Table 5).

Table 5. The state of the Woods in 1950 (Anon 1950)

\begin{tabular}{|l|r|r|}
\hline & Extent (ha) & $\%$ \\
\hline Broadleaved & 62 & 18 \\
\hline Conifers & 5 & 1 \\
\hline Mixed & 11 & 3 \\
\hline Coppice/coppice with standards & 57 & 16 \\
\hline Unproductive open ground & 177 & 50 \\
\hline Biological and recreational reserves & 40 & 12 \\
\hline total & 352 & \\
\hline
\end{tabular}

The Woods were to be managed to improve, maintain and utilize the existing woodlands under an approved plan and in accordance with the practice of good forestry insofar as the special local conditions and conditions of ownership allow. The Woods were recognised to have a high amenity value which must be maintained and also their value for instruction and research (Anon 1950). They were 'not to be regarded primarily as a financial asset'. The bulk (277 ha) were however to be worked so as to create an irregular mixed broadleaved high forest, not necessarily of uniform composition throughout, nor precluding 
the use of coniferous species on short rotations where their use would help to achieve the main objective. The remaining 34 ha were to be worked as coppice.

The main thrust of the forestry activity in this period was the creation of plantations on the open ground of Radbrook Common. While broadleaved crops predominated these were frequently established with conifer 'nurse' crops in line with then best practice; the small scale and varied nature of these plantings is illustrated in Figure 3. Elton notes in passing the consequent changes in the nature of the habitats and species of the open common, but does not seem to have been too worried about this; indeed he saw the plantations as having some research potential (Table 6).

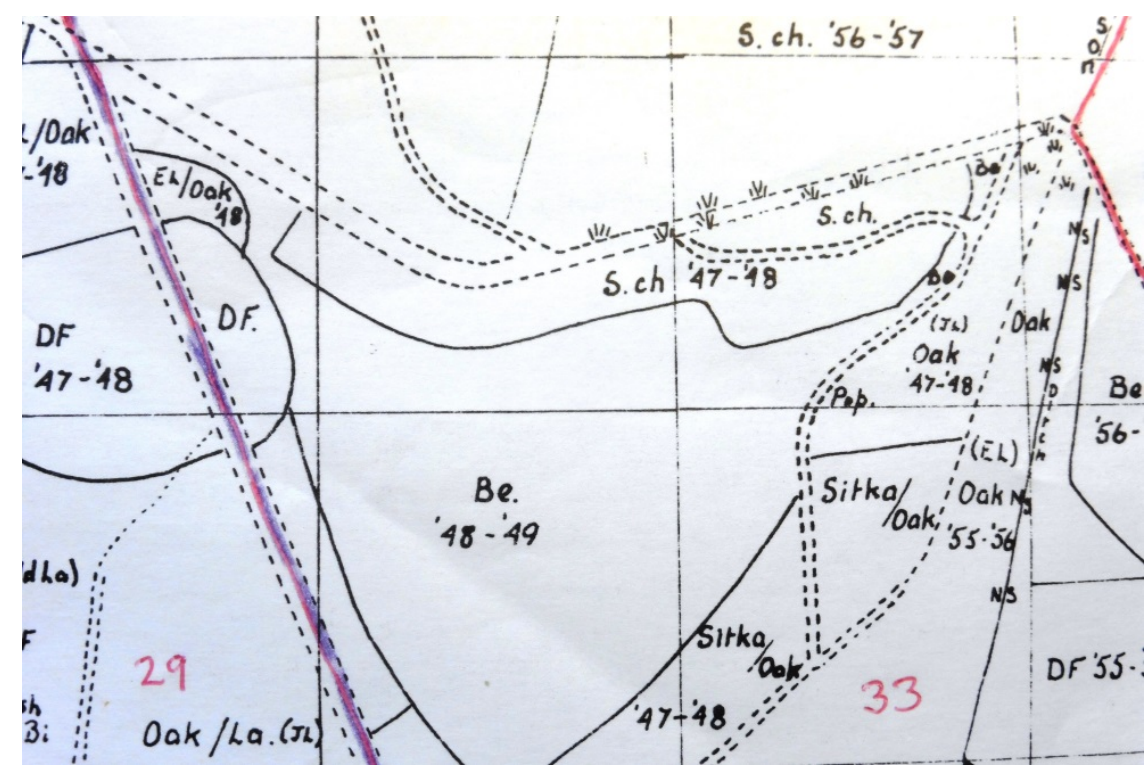

Figure 3. Planting on Radbrook Common: the abbrevations give the main crop species and planting date, so the stand in the centre - Be '48-49 - consists of beech planted in the winter of 1948-49. Each square represents one hectare (100m x 100m) (Extract from the Wytham Atlas (Smith 1987)

Table 6. Some positive reactions to the forestry management proposals (Elton 1942-1965).

March 1945. Professor Champion welcomes this project [looking at small mammals across the Woods]; conversely the type of silvicultural management proposed by Professor Champion will be beneficial to our work by giving the chance to experiment with changes of habitat.

7 April 1953 In the upper parts of Compartments 5 and 9 (Holly Hill Copse) and in 7 (Little Ash Hill) a great many societies of primrose are in flower and can be seen to be spreading to the edges with small seedling plants carrying one or a few flowers. ... The plants are multiplying wherever there has been thinning or other opening.

28 December 1957 Three red-polls (Carduelis flammea) ...were eating steadily the birch catkins at scrub canopy height in a thick young mixed plantation on Radbrook Common (= mixed scrub, 10-15 ft). This is their typical winter feeding habit. The whole of this complex and varied mosaic of plantings on Radbrook Common would begin to repay a survey now. 
A draft Wild Life Policy for the Woods was drawn up by Elton and discussed at the Advisory Committee in 1946. This noted that forest operations offer 'numerous chances of conducting biological operations and experiments on vegetation and other wild life' although they 'will without question reduce the variety of habitats for study' 'unless dovetailed into a general plan for safeguarding wildlife interests'. Key to this would be:

- Setting aside areas for scientific nature reserves (Figure 4), which were with minor modifications largely agreed;

- Rodent and predator control (generally agreed as discussed above);

- Policies of management of these reserves and of wild life in the Woods generally. It was on this last point, what happened outside the reserves, that the 'dovetail' fell apart.

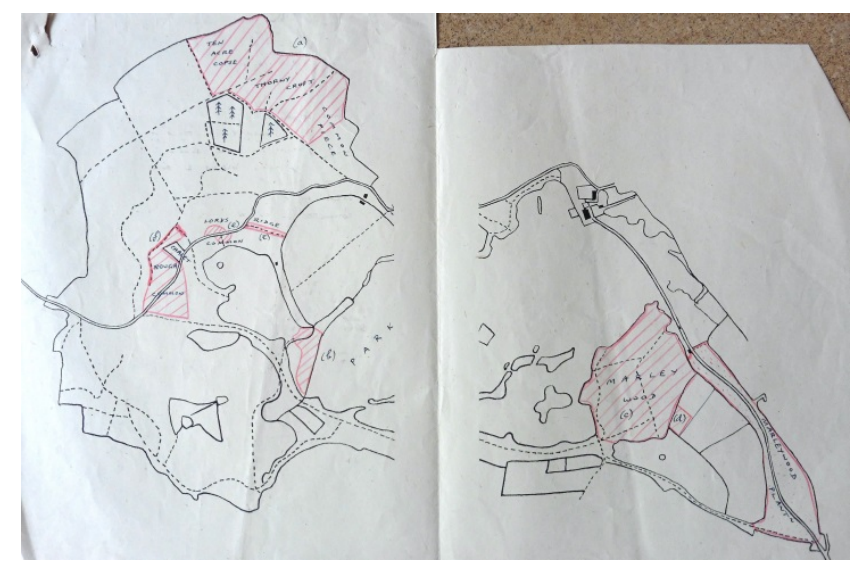

Table 7. The Biological Reserves proposals: summarised from 'A wildlife policy for Wytham Woods’ unpublished paper by C.S. Elton, November 1946.

- Woodland on northern edge: lies mostly on Oxford clay, with mixed wood and scrub, excellent for birds and small mammals, least disturbed part of the woods, abuts below on to the river meadows, good length of woodland margin conditions.

- Marley Wood - or as much of it as can be spared, including both woodland and open areas. The Edward Grey Institute use this heavily for their bird research; affords in present state the greatest pleasure to visitors for the variety and beauty of its vegetation and bird song. If not all can be a reserve its reafforestation should be delayed for say ten years.

- Various areas of grassland and associated habitats, noted for their rich flora, Brown Argus butterfly, occurrence of woodlark.

- The botanically important area around and below the lower pond on Radbrook Common should be added.

- Some of the rides are important for their flora and vehicle access should be limited.

Between the intensive management of the new plantations (of limited concern to the ecologists) and the largely minimum intervention approach being pursued in the Reserves, lay both physically and philosophically the management of rest of the woodland. This was a mixture of ancient woodland that had been felled and replanted during the $19^{\text {th }}$ century with much sycamore; $19^{\text {th }}$ century plantings of beech; and self-sown ash and sycamore growing up amongst scattered old trees on former common land (Kirby et al. 2014). Many of these crops were over-mature or very open (in part because of war-time fellings) and the prescriptions advocated by the Forestry Department were typically to clean them up and then replant them in line with common practice elsewhere. 
A complication was that in 1952 the Woods had been entered into the Forestry Commission's Dedication Scheme. The Dedication Scheme (Basis II) was introduced after the Second World War to encourage home-grown timber production. Owners who entered the scheme agreed to 'dedicate' their woodland; that it would remain woodland in perpetuity (many woods were otherwise being lost to clearance for agricultural intensification, another strand of Government post-war policy); and that timber production would be a major objective. The woodland owner was then eligible for grants to assist planting and annual management costs; commercial woodland was also favourably treated under various parts of the tax regime.

The University had started discussions on putting Wytham Woods into Dedication in 1947, albeit excluding the areas that were to become the biological reserves. It was feared that the Forestry Commission might otherwise compulsorily take over the management of the Woods. While legally the Commission did have such powers they were never exercised after the war. The Dedication Covenant was signed in1952 and by doing so the University committed itself to the first of a series of ten-year plans of forestry operations. Between 1949 and 1960 the University had received payments of $£ 3347$ and other eligible work already done was due to attract a further $£ 1840$. (Based on Annex to Hebdomonal Council Report for 1962). Moreover there was some pressure on the Forestry Department (from the Forestry Commission) to work faster through the 'unproductive' areas.

However, during the 1950s, as the programmes of felling, thinning and planting moved through the older woodland, Elton and others became increasing unhappy with the whole approach (Table 8). They saw a major loss of wildlife interest and research potential in the large-scale clearances with consequent loss of mature trees and scrubby edges to stands; the removal of existing dead wood and loss of potential future dead wood for many years; broadleaved stands with a varied structure (particularly important for birds and invertebrates) being replaced by uniform stands in which non-native conifers were often dominant. Even some badgers were killed in the name of forestry practice, presumably because they were breaking through the rabbit netting needed around young plantations.

Table 8. Rising concerns over the forestry management (Elton 1942-65))

17 February 1953 Great clearances have been made in parts of Lord's and Hill Copses (19-21) but they have not yet begun on 17 and 15, though we saw trees marked with red blazes for felling this season, in 17 . The pattern is now fairly plain and is immediately ruinous to many ecological interests, though opening out certain new values. The immediate and sweeping changes are that instead of a moderately thick scrub-tree canopy over much of the ground (not, admittedly, high forest canopy) you have:

(1) Anything from almost clear-felling of everything except scattered seed/timber oaks and ashes and sycamores, to a less drastic pattern, with e.g. groves of young ash or sycamores left to develop.

(2) From a dullish ground flora of, say, mercury with a few other species, an outburst may be expected of (a) spring flowers like bluebell and primrose (b) grass tussocks, especially Holcus and Deschampsia (c) bracken or bramble. The results may blend into a typical oak wood seasonal cycle, or the grass or bracken may dominate. This is partly deduction and speculation. Bracken 
will be one huge trouble of the foresters when they thus remove canopy in some areas. Also bramble.

(3) All scrub is cut away, which of it will come back, and from roots or new seed? Will it be cut away on every 3-5 year thinning blitz?

(4) All dead and decaying timber, all logs, are whisked away. There are still good specimens of both in Compartment 17. Here also is a much smaller maple which may be removed. No dead wood is left except what may remain on reprieved seed/timber trees, and a good many stumps, some of which will die quite, other coppice. No dead wood could arrive for 20 years except by decay and windfall of the reprieved trees, which would then be exploited anyway.

(5) The Compartment spaces are planted at about $5 \mathrm{ft}$. intervals with young oak, ash etc., and spruce, larch, Thuja, etc. It is intended to use the conifers mainly as fairly long-term nurses only, leaving a mixed but utterly healthy deciduous forest at the end.

(6) Small spring flushes with Carex e.g. acutiformis or hollows with Juncus inflexus etc. Will remain and cannot be eliminated, except by eventually heavy canopy.

(7) (5) requires rabbit fencing (lasting 8-10 years) which the badgers pushed through. If they do not, their territory gets restricted. I think visitors will be discouraged from hopping these fences.

(8) After the first drastic reorganisation there will be a long stage up to the cutting of the mature timber, when the compartments will not be ever so suddenly changed, though there will be periodic thinning etc. The field layer will be very varied and beautiful, scrub may infiltrate again, but DD/wood will have to be provided deliberately.

16 April 1955 Visited slopes below the Chalet and Further Clay Hill [part of Great Wood]. The latter has been (except for reserve below) absolutely desolated by this winter's forestry. It is practically bare, only scattered young trees, thickening as you go upwards. Planted with oak, beech, and some spruce etc.

29 August 1956 The Singing Way is now coming under forestry attention. It was stated that a 15 yd. strip would be left untouched either side. But they are in fact clearing and burning underbrush and singling old coppice stems very near to the track.

3 September 1956 This afternoon I marked out four areas on the steep slopes of woodland by the big badger earths below the Chalet and along to the rocky escarpment north-east of them, in Comp. 18. The badgers had been destroyed in the interests of forestry, but their huge sandy mansions all show signs of slight reoccupation, and the roadways through the dog's mercury are still well-marked.

8 November 1956 Osmaston says that all the old (and gorgeous low spreading and beautiful) beeches along the Singing Way (which is included in dedication agreement) will gradually be removed and replaced by groups of (mainly) other deciduous species. This policy needs some attention.

25 February 1957 Went with Prof. Champion and Col. Lloyd (Forestry Department) and David Lack to agree on a compromise plan for the future of Marley Wood. It is in the Forestry Dedication Plan; no work will be done for five years except some thick-coppice 
thinning; but it would then fall in for virtual extermination by clearing and replanting. It was finally agreed to reserve for science all of it except a large patch (consisting mainly of dark overgrown hazel coppice with a few deciduous standards like oak and birch and ash) carved from Compartments 38 and 39. Lack needs this for the next 5 years or so, but his tit work can then finish on that part of the wood.

14 December 1960 The whole of Comp. 15 and 14 have now been given the full forestry "planting" treatment, the west end in previous recent years, the east end now in progress. 14 has all the large trees (mainly oaks) lying fairly new-felled. The scrub is all out, but for a few patches. Patches of bracken cut or rolled. The planted trees on 15 are growing to the 6 foot height range - rows of spruce, oak, beech and some ash, with the occasional border of Lawson's cypress. 4 pheasants rose from here. Only a few minor groups of young trees are left. And this is the treatment that had been planned for a further 200 or more acres, at the rate of 12 acres a year; but this may be averted now.

21 March 1961 Compartment 18 is having its going-over by contractor bandits, who have felled a large number of larger trees, oaks especially, and the place is in a mess. But it is not in any degree a clear-felling, but a cutting out of older trees disapproved of by forestry.

\section{A CRISIS IN MANAGEMENT}

The second ten-year management plan (Osmaston 1959) essentially proposed a continuation of the approach set out in the 1950s, because of 'the distressingly large areas of idle unproductive land classified as blank, scrub or hazel coppice, all of which require reforestation as soon as possible". The ecologists did not view things in quite this way and objected that virtually all the Woods, except the reserves, would end up being intensively worked.

In December 1960 the idea of a more equal split of the Woods between the ecologists and the foresters was proposed. F.C. Osmaston of the Forestry Department was put on the spot and asked what area it needed to carry out its teaching and research roles. A figure of 350 acres (140 ha) was suggested, but at the Advisory Committee the following March, the new forestry professor M.V. Laurie revised this back up to 600 acres (240 ha). Laurie stressed that he viewed it as a matter of principle that the previously agreed balance between reserves and productive forestry (in favour of the latter) should be adhered to.

Elton's response was that the management that had been going on in the 1950s was not what had been understood to be the plan in the 1940s; that there had not been adequate with ecological researchers about the implications of putting the woodland into the Forestry Commission's Dedication Scheme; and that he had been assured in 1955 that 'the most drastic stages for clearing are now nearly completed' yet here were 'another 200 acres (80 ha) to be so treated'.

In the minutes of the March meeting Mr Bredin (representing the Curators of the University Chest) noted that if the Forestry Department could not reduce its demands for 600 acres (240 ha) then the University would have no alternative but to cut it down to 350 (140 ha) and hand over management to the Land Agent. A further meeting between the Forestry Department and the ecologists in June 1961 once more failed to produce a compromise. The report that subsequently went to Hebdomonal Council (the University's governing body) (Curators of the University Chest 1961a) includes the statement 'If the proposals of the 
Forestry Department prove unacceptable to Council it has been intimated that they would no longer wish to continue the management of the woods'.

A further report (Curators of the University Chest 1961b) to Hebdomonal Council stressed the following as important for maintaining the amenity of the Woods in order to comply with the wishes of the donor (Colonel ffennell):

- Preservation of present character of the woodland on either side of certain of the principal rides through the woods which are most frequented by permit holders;

- Preservation of the general appearance of the woods as seen from outside their perimeter;

- Preservation of the views of the surrounding countryside and of Oxford as seen from the principal vantage points on Wytham Hill;

- Retention of a large number of large trees and no large and conspicuous blocks of conifers.

The Curators of the University Chest strongly endorsed the view that it was unlikely to be 'possible to conduct the most efficient methods of forestry on much more than the 300 acres [120 ha] contemplated by the Advisory Committee without seriously impairing the beauty of the woods as a whole. At the same time as long as amenity is accepted as the overriding consideration the committee sees no reason why a modest amount of felling and planting, or regeneration, should not take place, provided conifer nurses are not used to any great extent and certain amount of supervision and control is exercised. All that is required is that management which is essential should be judicious and not go too fast...' 'Nor should any operations be allowed that would substantially alter its present picturesque if somewhat unkempt state, which indeed provides its great attraction'. Hebdomonal Council agreed with this view.

The Forestry Department's bluff had been called and their management plan was withdrawn. There was no provision for actually taking the Woods out of Dedication but the agreement with the Forestry Commission was effectively suspended and $£ 4300$ worth of grants repaid.

\section{A NEW DIRECTION FOR THE 1960S}

The tensions described for Wytham Estate mirror much of what was happening in the countryside more generally as Britain emerged from the Second World War. Farming intensified initially to provide food from our own resources and the landscape around the Woods changed accordingly. Game management was still widespread; gibbets dangling with vermin could still be encountered into the 1980s. The justification for forestry shifted from creating a strategic timber reserve to economic timber production and hence increased emphasis on use of conifers (Tsouvalis 2000; Foot 2010). Extensive areas of ancient seminatural woodland were felled and replanted (Spencer and Kirby 1992) as would have happened further in Wytham if Elton had not intervened so effectively.

Could a compromise have been agreed? Neither the University nor Elton was opposed to some of the woodland being actively managed for timber. Eustace Jones in the Forestry Department was interested in the structure of natural woodland (Jones, 1945) and long-term ecological monitoring, having set up the permanent transects in Lady Park Wood 
in Gloucestershire (Peterken and Jones 1987; Peterken and Jones 1989). There was clearly a cross-over of interests. The Forestry Department would have had to accept more restrictions on the extent and nature of its activities, but Elton had been able to negotiate at least some changes along these lines (Table 9) already. Ironically these could be seen as the forerunners of the types of guidance introduced to forestry policy and practice more generally during the 1980s and 1990s (Forestry Commission 1985; Forestry Commission 1994; Leslie, 2014).

Table 9. Developing conservation guidelines (Elton 1942-65)

21 April 1953 Probitts agreed to leave a strip of scrub with spindle and several very large wayfaring trees, at the end of the path from the Chalet to Upper Seeds (by the beech wood).

4 May 1953 [Main road through Marleywood Plantation] Agreed to try and arrange labour to (a) keep a clear herb-grass verge from 2-10 yd. -- wider in the open space (b) start by slashing the scrub and then employ a mechanical cutter machine annually (c) to keep the herb component, do the cutting between August and October -- not earlier. This will at any rate provide an experiment in management.

9 November 1955 Met Probitts and arranged the safeguarding and future treatment of the major dying and dead trees, and logs in Marleywood Plantation; also the conservation of streams for Eccles' work. The general agreement with Probitts is:

1) Leave all labelled trees unexploited, including all lying branches and old decayed logs near them.

2) So far as possible do this with any other (unmarked) DD/Wood. However, immediately fell dead and dangerous dead beech (Log 22), and later on the dead standing beeches of Logs 29 and 30. Agreed that with these, and also on the fallen Logs 28 and 20, the smaller branches could be cut and cleared if desired for tidiness and silviculture, but roughly leaving all stuff more than 6 in. diameter.

3) Bramble (and for Log. 29) scrub cover to be left.

2 December 1955 Walked in the woods along the Singing Way between My Lady's Seat and level with the Pasticks, to note the dead tree and logs situation. There are several score of boles, dead branches and logs, and one or two dead trees. Some are very old, others fresh. Decided that it would be simplest to ask for a blanket order to the Forester to leave all standing dead boles of all species, all rotting logs and stumps,

26 July 1964 Ride management along the Singing Way is very successful. The centre is machine-cut sward; the edges have huge Heracleum and tall grasses such as Festuca gigantea. One side will be cut in September, the other next year.

A reduced forestry programme could have been combined with an expanded programme of research into the ecology of the plantations that had already been created Elton appreciated their potential for experimental alteration of conditions. We might then be in a much better position now to answer questions on the effects of woodland management on the diversity of different groups of organisms (Gotmark, 2013). However it was not to be. My impression is that by 1961 positions had become entrenched with each side convinced that only they knew what was best for the Woods. Elsewhere in Britain a similar attitude bedevilled debates about conservation and forestry through into the 1980s. 
Back in Wytham relationships between foresters and ecologists did however improve, particularly through the efforts of Colyear Dawkins from the Forestry Department who joined the Advisory Committee for the Woods during the 1970s. The lower key approach to management after 1961 did not however mean that the Woods stopped changing. Some thinning continued but more significant changes occurred through 'natural processes': stand growth and competition; changing herbivore pressures, succession on grassland and the impact of extreme events such as disease and storms. These factors caused as radical changes as would have happened under an active forestry programme and have triggered the need for much more active conservation management that might otherwise have been the case. They will be explored in a separate account.

\section{CONCLUSION}

The diary entries and committee papers, along with various photographs from the period, have enabled us to fill an important gap in our understanding of the recent history of Wytham Woods and the individuals who helped to shape their management. Such material might easily be dismissed as trivial, because each item by itself often reveals little or lacks detail. However taken together they tell an important story.

Will the same be the case for records made today? Far fewer people keep paper diaries, but the advent of digital photography means that it is far more likely that there will be images of how Wytham Woods and other sites look, if they can be found. So there is still a case for trying to ensure that accounts and pictures are catalogued, published or archived in some form. Otherwise future historians may end up trawling the Facebook entries of current visitors and researchers in the Woods.

\section{REFERENCES}

Anon., 1943. Wytham: a record issued by the Oxford Preservation Trust on the acquisition of Wytham Abbey ad Estate by the University of Oxford. Oxford: Oxford University Press.

Anon., 1950. Working plan for 1949/50-1959/60 for the Woods of Hazel, Wytham, Berkshire. Oxford: Unpublished MS.

Crowcroft, P., 1991. Elton's ecologists: a history of the Bureau of Animal Population. Chicago: University of Chicago Press.

Curators of the University Chest, 1961a. Further report on Wytham Woods. Hebdomonal Council Minutes 10 November 1961. Volume 240, 357-361

Curators of the University Chest, 1961b. Report of the Biological Advisory Committee on Wytham Woods. Hebdomonal Council Minutes 21 July 1961. Volume 239, 885-899.

Elton, C.S., 1942-1965. Elton Archive: notes on the Wytham Area 1942-1965. Available at http://ora.ox.ac.uk/objects/uuid:89c5e479-6003-45ba-bd78-8a8a12858bf1.

Elton, C. S., 1966. The pattern of animal communities. London: Chapman and Hall.

Foot, D., 2010. Woods and people: putting forestry on the map. Stroud: The History Press.

Forestry Commission, 1985. The policy for broadleaved woodland. Edinburgh: Forestry Commission.

Forestry Commission, 1994. The management of semi-natural woodland: guides 1-8. Edinburgh: Forestry Commission.

Gibson, C. W. D. and Kirby, K. J., 2010. Woods ancient and modern - land-use history. In: Savill, P. S., Perrins, C.M., Kirby, K. J. and Fisher, N. eds Wytham Woods: Oxford's ecological laboratory. Oxford: Oxford University Press, 29-41. 
Gotmark, F., 2013. Habitat management alternatives for conservation forests in the temperate zone: review, synthesis and implicaitons. Forest Ecology and Management, 306, 292307.

Grayson, A. J. and Jones, E. W., 1955. Notes on the history of the Wytham Estate with special reference to the woodlands, Oxford: Imperial Forestry Institute.

Jones, E. W., 1945. The structure and reproduction of the virgin forest of the north temperate zone. New Phytologist, 44, 130-148.

Kirby, K. J., Bazely, D. R., Goldberg, E. A., Hall, J. E., Isted, R., Perry, S. C. and Thomas, R. C., 2014. Changes in the tree and shrub layer of Wytham Woods (Southern England) 1974-2012: local and national trends compared. Forestry, 87, 663-673.

Leslie, R., 2014. Forest Vision:transforming the Forestry Commission., Bristol: New Environment Books.

Osmaston, F. C., 1959. The revised working plan for the Wytham Woods 1959/60-1968/69, Oxford: Unpublished MS.

Perrins, C. M., 2010. Introduction. . In: Savill, P. S., Perrins, C.M., Kirby, K. J. and Fisher, N. eds Wytham Woods: Oxford's ecological laboratory. Oxford: Oxford University Press, 1-17.

Peterken, G. F. And Jones, E. W., 1987. Forty years of change in Lady Park Wood: the old growth stands. Journal of Ecology, 75, 477-512.

Peterken, G. F. And Jones, E. W., 1989. Forty years of change in Lady Park Wood: the young growth stands. Journal of Ecology, 77, 401-429.

Savill, P. S., Perrins, C.M., Kirby, K. J. and Fisher, N., 2010. Wytham Woods, Oxford's Ecological Laboratory. Oxford: Oxford University Press

Sheail, J., 1971. Rabbits and their history. Newton Abbot: David and Charles.

Smith, P., 1987. Wytham Woods Atlas $3^{\text {rd }}$ edition. Unpublished. Oxford: Wytham Woods Office.

Southern, H. N., 1955. A Britain without rabbits. Discovery, 16, 186-189.

Tsouvalis, J., 2000. A critical geography of Britain's state forests. Oxford: Oxford University Press.

UNPUBLISHED PAPERS (from files held by the Conservator of Wytham Woods)

31 March 1944. Letter from C.S.Elton to H.G. Champion about ways to control rabbits at Wytham.

16 March 1945. Note on Shooting on the Wytham Estate. Unpublished paper by H.N.Southern, with hand-written annotation by C.S.Elton.

15 June 1946. Letter from C.S.Elton to A.J. Spencer (University Chest) concerning problems of poisoning of badgers and foxes.

9 September 1946. Letter from R.J.Venables to H.N. Southern reporting weekly bags for rabbits from June to August.

28 November 1946. A wildlife policy for Wytham Woods. Unpublished paper by C.S.Elton presented to the Biological Committee for Advice on University Estates.

30 November 1946. Letter from C.S.Elton to H.G.Champion about rabbit control being left in hands of shooting tenant.

9 March 1961. Sub-committee for Wytham Estate Report January to December 1960 - pest control. Unpublished paper

26 May 1961. Minutes of the Advisory Committee on the Biological Aspects of the Management of the Landed Estates of the University and Colleges meeting on 9 March 1961.

1962 Annex to Council Report, pages 552-558 dealing with the decision to remove Wytham Woods from the forestry Dedication Scheme. 
